\title{
GEOELECTRICAL MODEL FOR AQUIFER IN THE BONITA LAKE REGION, PLANALTINA, DISTRITO FEDERAL, BRAZIL
}

\author{
Carlos T.C. do Nascimento ${ }^{1}$, José Vicente E. Bernardi ${ }^{2}$, Andréia de Almeida ${ }^{3}$, \\ João Cândido Magalhães ${ }^{4}$ and Paulo Milton B. Landim ${ }^{5}$
}

\begin{abstract}
The aim of this study was to analyze the soil geoelectric behavior, through geophysical surveys, in the surrounding region to Bonita Lake, a natural reservoir located in the Ecological Station Águas Emendadas (ESECAE), 50 kilometers from Brasília (Brazil). Sixteen vertical electrical sounding (VES) were performed with Schlumberger array. The geoelectrical model, obtained by inversion of the field data and statistical analysis of the inverted data, indicated structure with superficial dry soil above partially saturated layer, and finally a soil or rock with low permeability, related to the aquifer formation with varying thickness, about ten meters below the lake and up to twenty meters deep in the surrounding area. The VES showed that the aquifer has great lateral extension to the north, east and west of the lake; providing water to the same, while in the south, the aquifer is possibly limited by quartzites of the Canastra Group. This restriction can result in the absence of aquifer recharge in the southern portion, and coincides with the region where the lake drains into the source of Mestre D'Armas stream. This information is important because it can be used in the delineation of the hydrogeological basin and the Bonita Lake protection perimeter.
\end{abstract}

Keywords: Ecological Station of Águas Emendadas, aquifer, vertical electrical soundings.

RESUMO. 0 objetivo deste estudo foi analisar o comportamento geoelétrico do solo, por meio de levantamentos geofísicos, na região circundante à Lagoa Bonita, um reservatório natural localizado na Estação Ecológica de Águas Emendadas (ESECAE), a 50 quilômetros de Brasília (Brasil). Foram realizadas dezesseis sondagens elétricas verticais (SEV) com arranjo de Schlumberger. Os modelos geoelétricos, obtidos pela inversão dos dados de campo e análise estatística dos dados invertidos, indicaram uma estrutura com solo superficial seco sobreposto a uma camada parcialmente saturada e, por fim, um solo ou rocha com baixa permeabilidade, referente à formação aquífera, com espessura variável, cerca de dez metros abaixo da lagoa e até vinte metros de profundidade na área circundante. As SEV demonstraram que 0 aquífero possui grande extensão lateral para norte, leste e oeste da lagoa; fornecendo água para a mesma, enquanto que, na direção sul, o aquífero é possivelmente limitado por quartzitos do Grupo Canastra. Esta restrição pode resultar na ausência de recarga do aquífero na porção sul, e coincide com a região onde a lagoa drena para a nascente do ribeirão Mestre D’Armas. Esta informação é importante, pois pode ser utilizada no processo de delimitação da bacia hidrogeológica e delimitação do perímetro de proteção da Lagoa Bonita.

Palavras-chave: Estação Ecológica de Águas Emendadas, aquífero, sondagem elétrica vertical.

\footnotetext{
1 Universidade de Brasília - UnB, Campus Planaltina, DF, Brazil. Phone: +55(61) 3107-8052 - E-mail: carlostadeu@unb.br

2Universidade de Brasília - UnB, Campus Planaltina, DF, Brazil. Phone: +55(61) 3107-8051 - E-mail: bernardi@unb.br

3Universidade de Brasília - UnB, Campus Darcy Ribeiro, DF, Brazil. Phone: +55(61) 3107-8052 -E-mail: andreiaalmeida.df@gmail.com

${ }^{4}$ Universidade de Brasília - UnB, Campus Planaltina, DF, Brazil. Phone: +55(61) 3107-8052 - E-mail: candido.magalhaes@hotmail.com

5 Universidade Estadual Paulista - UNESP, Campus Rio Claro, SP, Brazil. Phone: +55(14) 3882-8364 - E-mail: plandim@rc.unesp.br
} 


\section{INTRODUCTION}

Groundwater contributes significantly to the hydrological cycle and supplies approximately half of the world population, especially in semi-arid regions (Mierzwa \& Hespanhol, 2005). Approximately $65 \%$ of the Brazilian population is supplied for domestic purposes with groundwater; $7 \%$ use shallow wells, $12 \%$ are supplied directly from springs or fountains, and $47 \%$ are supplied through deep wells (IBGE, 2008). According to the database of the regulatory agency for water and sanitation of the Distrito Federal (ADASA), the main uses of groundwater in the Distrito Federal/Federal District (DF), where the Brazilian capital is located, include domestic supply, irrigation, and industrial use (Mello \& Castro, 2011). Due to the types of aquifers in the DF, groundwater should be used as a strategic resource applied to specific sectors of the economy or as a supply source for small urban centers and rural centers.

Given the economic, social and environmental importance of subsurface water resources, monitoring becomes an essential aspect of their proper management. This monitoring can be performed directly, by collecting and analyzing water samples, or indirectly, commonly by geophysical methods. The most used geophysical method in studies on subsurface water is the DC electrical resistivity method, and there are numerous studies demonstrating the suitability of this method for the aim of determining the depth of subsurface water (Steinich \& Marín, 1996; Zhou \& Sato, 2001; Nyquist et al., 2008; Cutrim \& Shiraiwa, 2011).

The electrical resistivity is a physical property of each substance, related to the greater or lesser difficulty of electric current passing through the substance. Rocks and soils, in general, are highly resistive, but the higher levels of humidity and greater amounts of material solubilized in the interstitial water origin can decrease electrical resistivity. The resistivity of the soil depends on at least the following factors: the degree of saturation; the resistivity of the fluid in the pores; porosity; the size, shape and distribution of the solid particles; and the thickness and composition of the cationic layer of mineral clays (Fukue et al., 1999).

Since the late nineteenth century, several attempts have been made to determine moisture and soil salinity from measurements of electrical resistivity. However, the mathematical correlations between these parameters usually have very limited application due to the large spatial variability of other soil parameters such as structure, texture, porosity and hydraulic conductivity, which directly influence the moisture content (Edlefsen \& Anderson, 1941; Kirkhan \& Taylor, 1950; Rhoades \& Ingvalson, 1971; Rhoades \& Van Schilfgaarde, 1976; Rhoades, 1979; Gardner, 1986; Frohlich \& Parke, 1989; Nascimento et al., 2004).

However, for providing indirect information of the subsurface geophysical surveys has increased the predictability of groundwater flow models (Sandberg et al., 2002). Calamita et al. (2012) found that the electrical method DC proved to be suitable for monitoring temporal and spatial variations of soil moisture in small and medium-sized watersheds. In the western part of Iran, Tirzo et al. (2012), estimated based on data soil electrical resistivity, related information will porosity and specific yield capacity of the aquifer under study.

The purpose of this work is to present the results of a geophysical survey surrounding Bonita Lake, a natural reservoir situated in the Estação Ecológica de Águas Emendadas (ESECAE), an environmental conservation unit in the northwest quadrant of DF. The procedure known as vertical electrical sounding (VES) was used to obtain information on the vertical variation of the electrical resistivity. In the study area, the variation of this property is conditioned mainly by the volume of water present in soils and rocks, and thus the depth of the water table is obtained indirectly.

\section{MATERIAL AND METHODS}

\section{Field of Study}

The ESECAE environmental conservation unit is located 50 kilometers from the center of Brasillia, close to the town of Planaltina (Fig. 1). It has approximate area of 10,500 hectares and is bisected by the DF-128 road so that two subareas are defined, respectively the Major Polygon and Minor Polygon. In the Major Polygon lies the common source of drainages flowing into the Parnaíba River Basins (Platinum Basin) and Tocantins (Amazonic Basin). In the Minor Polygon lies Bonita Lake, a natural reservoir, which is fed primarily by subsurface water and which is the source of the Mestre D'Armas River (Parnaíba Basin).

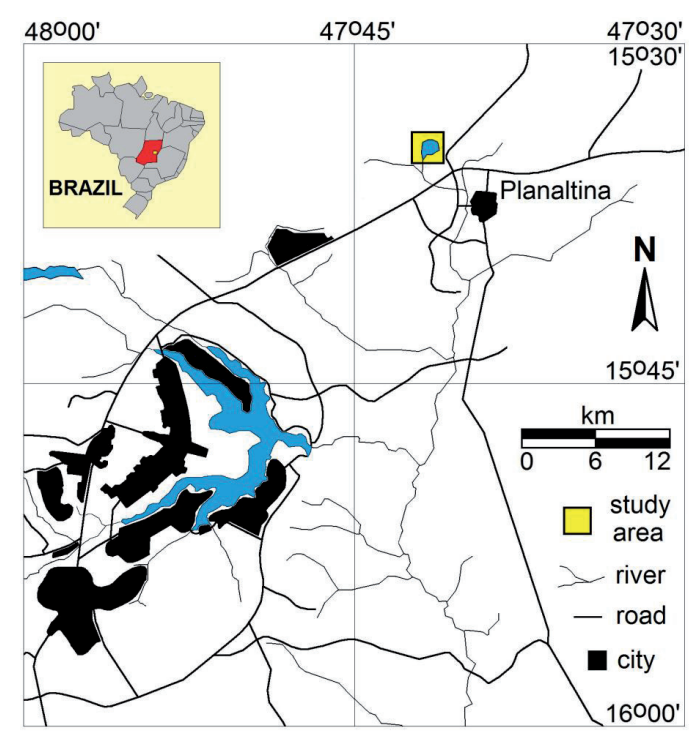

Figure 1 - Location map of the study area. 
The study area, included in the Cerrado region, presents an Aw tropical climate, defined by Koppen as a savannah climate with an average temperature of $22^{\circ} \mathrm{C}$, average monthly evapotranspiration of $65 \mathrm{~mm}$ and annual rainfall of approximately $1500 \mathrm{~mm}$, distributed mostly between October and March (Maia \& Baptista, 2008). With respect to soil conditions (Fig. 2), Red Oxisols (RO) and Red-Yellow Oxisols (RYO) predominate in the study area. Oxisols are highly weathered, deep soils with good drainage. In addition, Inceptsols (IS) and Entisols (ES) also occur (IBGE, 2007; Santos et al., 2013).

According to studies on the DF geology, in the Bonita Lake region, there are rocks of Proterozoic age, belonging to the Canastra and Paranoá Groups (Fig. 3). The Canasta Group
(MNPcmo) occurs south of Bonita Lake and consists mainly of phyllites and quartzites (Martins et al., 2002). The Paranoá Group is represented by two of its units, respectively Psammo-PeliticCarbonate (MNPpppc) immediately north of the Lake and Clay Metarrithmite (MNPpr4), between the Lake and the area of occurrence of the Canastra Group (Moraes \& Campos, 2008). The two units of the Paranoá Group consist of metargilites, metasiltstone and quartzites, differing by the presence of limestone lenses in the carbonate unit (Martins et al., 2002).

Groundwater in the Bonita Lake area occurs in porous aquifers, corresponding to soils, and in fractured aquifers, represented by quartzites of the Canastra Group (Lousada \& Campos, 2005). Aquifer term represent a geological formation with

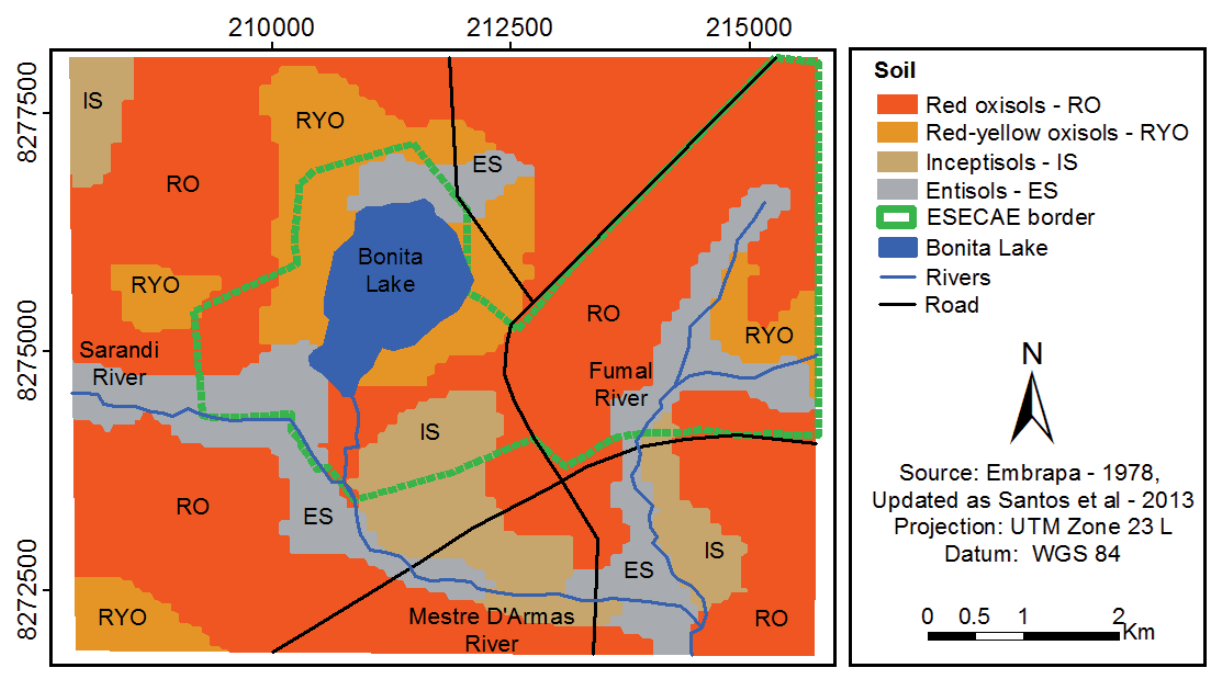

Figure 2 - Simplified pedological map of Bonita Lake area.

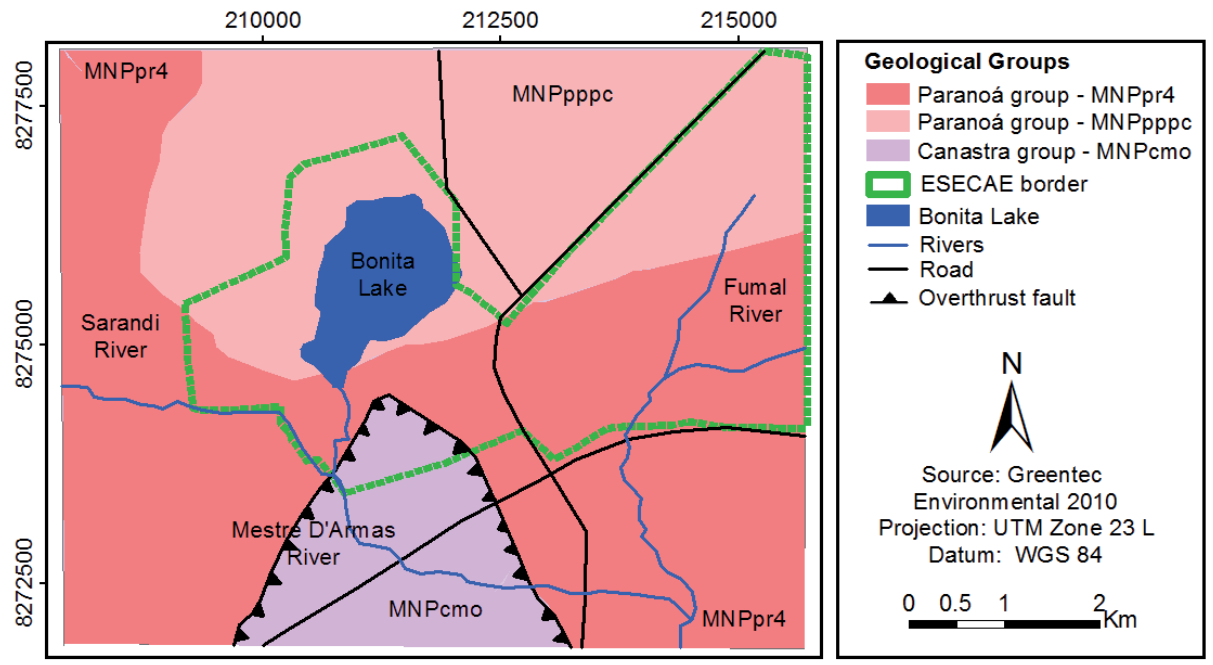

Figure 3 - Simplified geological map of Bonita Lake area. 
capacity to store and transmit water at rates fast enought to supply to wells (Freeze \& Cherry, 1979; Fetter, 1980; Cleary, 1989). The deep well that supplies the headquarters of the Center for Environmental Information of ESECAE, near Lake Bonita, was built in this geological unit. The observation tower located next to the Environmental Information Center is also located on the Canastra Group quartzites (Moraes \& Campos, 2008).

Bonita Lake possesses a surface of 120 hectares, an average depth of 1.5 meters and an estimated volume of 2.5 million cubic meters. In relatively small and shallow ponds, such as Bonita Lake, the modification of the local characteristics of the subsurface water flow and the utilization of such water through deep wells and cisterns can lower the water table and decrease the water entering the pond. This decrease can lead to the demise of the lake, especially in the dry season (Moraes \& Campos, 2008). Bonita Lake is not currently presenting problems related to reduced subsurface water removal or sealing of the basin (Moraes \& Campos; 2008; Bias, 2008). The occupation of its basin is limited to agricultural areas and access roads. Currently, agricultural practice are the greatest threat to the pond, causing the leaching of pesticides into the water body. The issue of lowering the water level, however, cannot be ignored, as the expansion of urbanization is observed mainly in the south of the Lagoon area, with the possibility of increasing the number of wells (Moraes \& Campos, 2008).

For a better understanding of the relationship between Bonita Lake and groundwater, it is important to implement monitoring of its water level as well as of the aquifer through the installation of piezometers at strategic locations. This type of monitoring, associated with a geophysical study examining the fractures, would be effective in defining the hydrogeological basin and consequently a protection perimeter for the pond (Moraes \& Campos, 2008).

\section{Electrical Resistivity Method}

In the DC electrical resistivity method, we work with two current electrodes ( $A$ and $B$ ) and two potential electrodes ( $M$ and $N$ ), all four set out on the soil surface. Through electrodes $A$ and $B$, we apply a potential difference, and as a result of this difference, a continuous electrical current begins to traverse the terrain. The value of the current is measured and recorded. Using electrodes $\mathrm{M}$ and $\mathrm{N}$, we measure a potential difference that is established in the field and is associated with the passage of current. It should be noted that the soil already has a natural electric potential, which should be subtracted from the measurement made with electrodes $\mathrm{M}$ and $\mathrm{N}$.

Based on the current flowing through the subsoil, the geometry of the arrangement of electrodes and the potential mea- sured between electrodes $\mathrm{M}$ and $\mathrm{N}$, one can calculate an electrical resistivity value. This value, measured in a heterogeneous and anisotropic medium and as a function of the electrode array, is known as the apparent resistivity (Orellana, 1972; Telford et al., 1990).

The determination of the vertical variation of resistivity is made by vertical electrical sounding (VES), whose interpretation is based on four assumptions:

1) The subsurface consists of a finite number of horizontal layers, each with finite thickness, except for the last one with infinite thickness.

2) Each of these layers is electrically homogeneous (no compositional variation) and isotropic (no variation of any property based on direction).

3) The current originates from a point source on the surface of the ground.

4) The current is continuous (Koefoed, 1979).

Altogether, sixteen vertical electrical soundings in the Bonita Lake area were performed, distributed along roads that surround this water body (Fig. 4). The field work was conducted between May, 2011, and January, 2012. The equipment used was a resistivity meter model ER-300 Pergeo. The VES were performed using a Schlumberger array and with 600 meters of maximum current electrode separation.

Measurements of apparent resistivity were processed using the Ridge Regression method (Tikhonov \& Arsenin, 1977) with IPI2win iteration software (Bobachev, Modin \& Shevnin; 2000) to delineate thickness subsurface layers and calculated resistivity. The IPI2Win is a program to analyze data from $1 \mathrm{D}$ geoelectric measurements on a single piece automatically or semiautomatically to get the smallest error (Niaz et al., 2013).

The inverse problem is solved using a variant of the Newton algorithm of the least number of layers or the regularized fitting minimizing algorithm using Tikhonov's approach to solving incorrect problems (Bobachev, Modin \& Shevnin, 2000). A priori information on layers depths and resistivities can be used for regularizing the process of the fitting error minimizing (Cutrim et al., 2007; Bobachev, Modin \& Shevnin, 2000).

\section{Statistical Method}

For statistical analysis of the data, we applied the method of cluster analysis. This analysis was performed to display the grouping pattern between layers of VES used in the geoelectrical sections, having as variables the values of apparent resistivity (Ohm.m) 


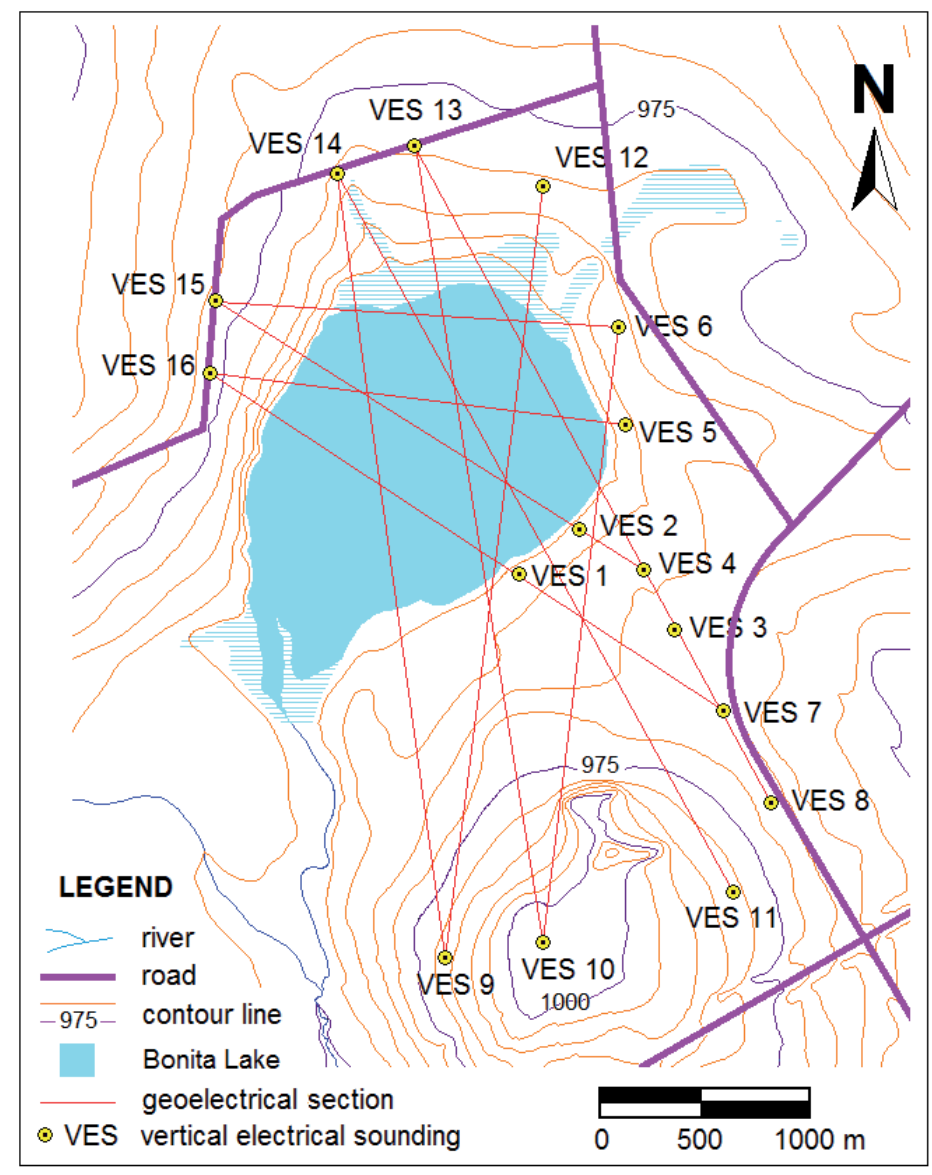

Figure 4 - Locations of VES in the Bonita Lake area. Source: SEDHAB (1997).

and thickness $(\mathrm{m})$ of each of the VES layers. For this purpose, the data were standardized, a procedure in which the mean is subtracted from the value of each variable, and the result is divided by the standard deviation (Borcard et al., 2011; Legendre \& Legendre, 2012). Using the standardized variables, we created a distance matrix with the Euclidean similarity index. The clusters were defined using the UPGMA clustering algorithmic procedure by "hclust" function in the R software (McQuitty, 1966; Sneath \& Sokal, 1973; Anderberg, 1973; Everitt, 1974; Hartigan, 1975; Murtagh, 1985; Becker et al., 1988; Gordon, 1999; Borcard et al., 2011).

To verify the significance of the generated clusters, we adopted a standard of a cophenetic correlation coefficient greater than 0.7 . The cophenetic correlation indicates the degree of fit between the original data matrix and the matrix resulting from the clustering method (Borcard et al., 2011; Legendre \& Legendre, 2012). This value is equivalent to the Pearson correlation between the original similarity matrix and the similarity matrix obtained through the construction of dendrograms (Borcard et al., 2011;
Legendre \& Legendre, 2012). Thus, the closer the cophenetic correlation coefficient is to 1 , the smaller the distortion caused by the clustering method adopted.

\section{RESULTS}

The apparent resistivity values were obtained from measurements made over a pre-determined spacing of $A B / 2$, ranging 1 300 meters. During processing, some values were discarded because they were anomalous and completely outside the general trend of the curves of field. Data were processed by providing graphs correlating the apparent resistivity with the spacing used (Figs. 5 and 6).

This curve in the graphs of Figures 5 and 6 is the result of the inversion performed with the markers representing the data field. The quality of the model can be evaluated by the closeness between the values obtained in the field and the curve constructed during processing. Based on the models, geoelectrical sections linking two or more VES were built. 

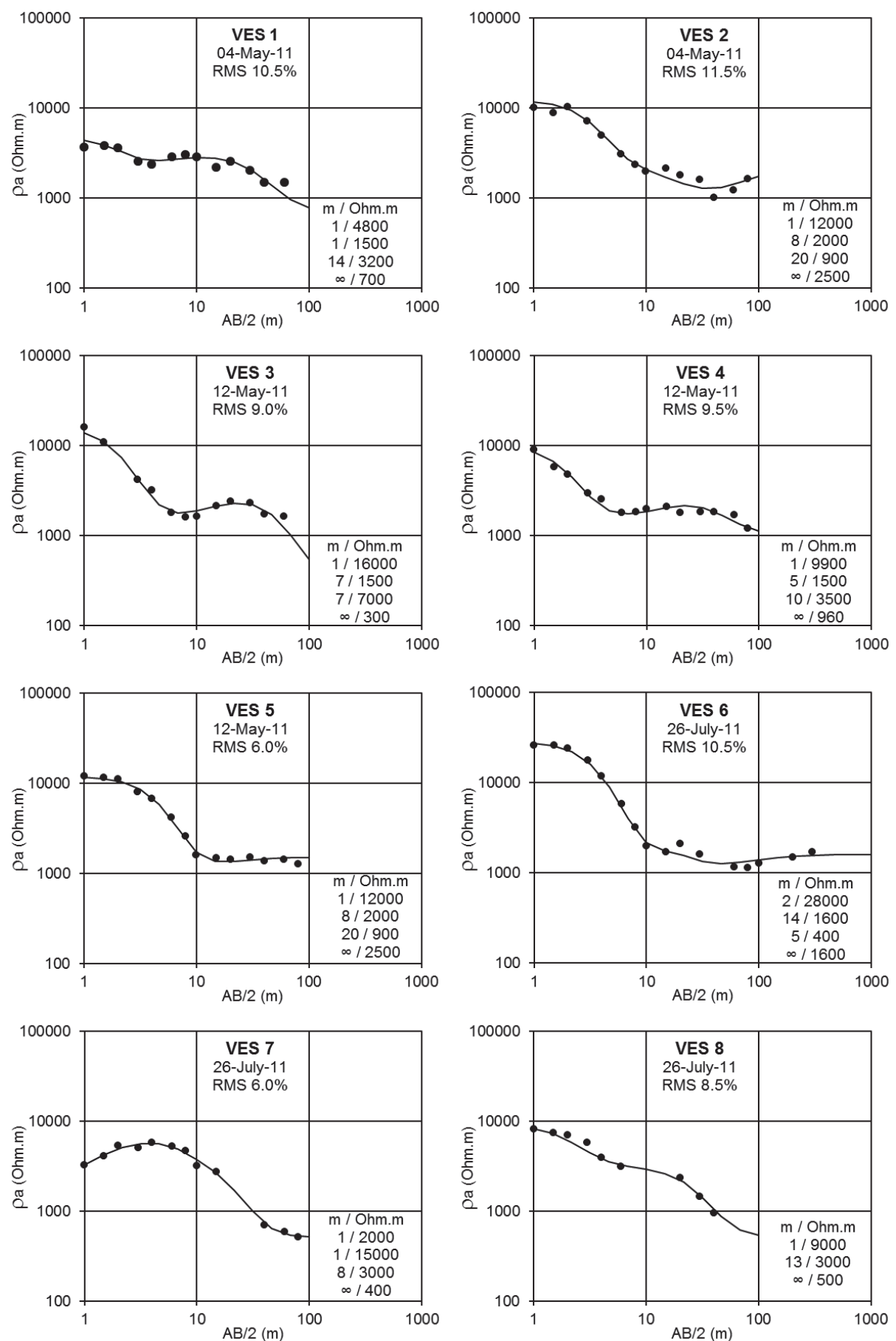

Figure 5 - Curves of vertical electrical soundings (VES) from 1 to 8 . The corresponding geoelectrical models are indicated in each graph.

Using these data, geoelectrical sections were prepared by linking two or more VES between the shores of Bonita Lake with a subset of dendrograms obtained through statistical analysis. Through applying cluster analysis to the variables of apparent resistivity (Ohm.m) and thickness (m) of the VES contained in geo- electrical sections, we observed a high correlation between the elaborated geoelectrical models and the clusters resulting from the analysis.

A cophenetic correlation coefficient above 0.7 represents a good correlation between the variables that characterize the 

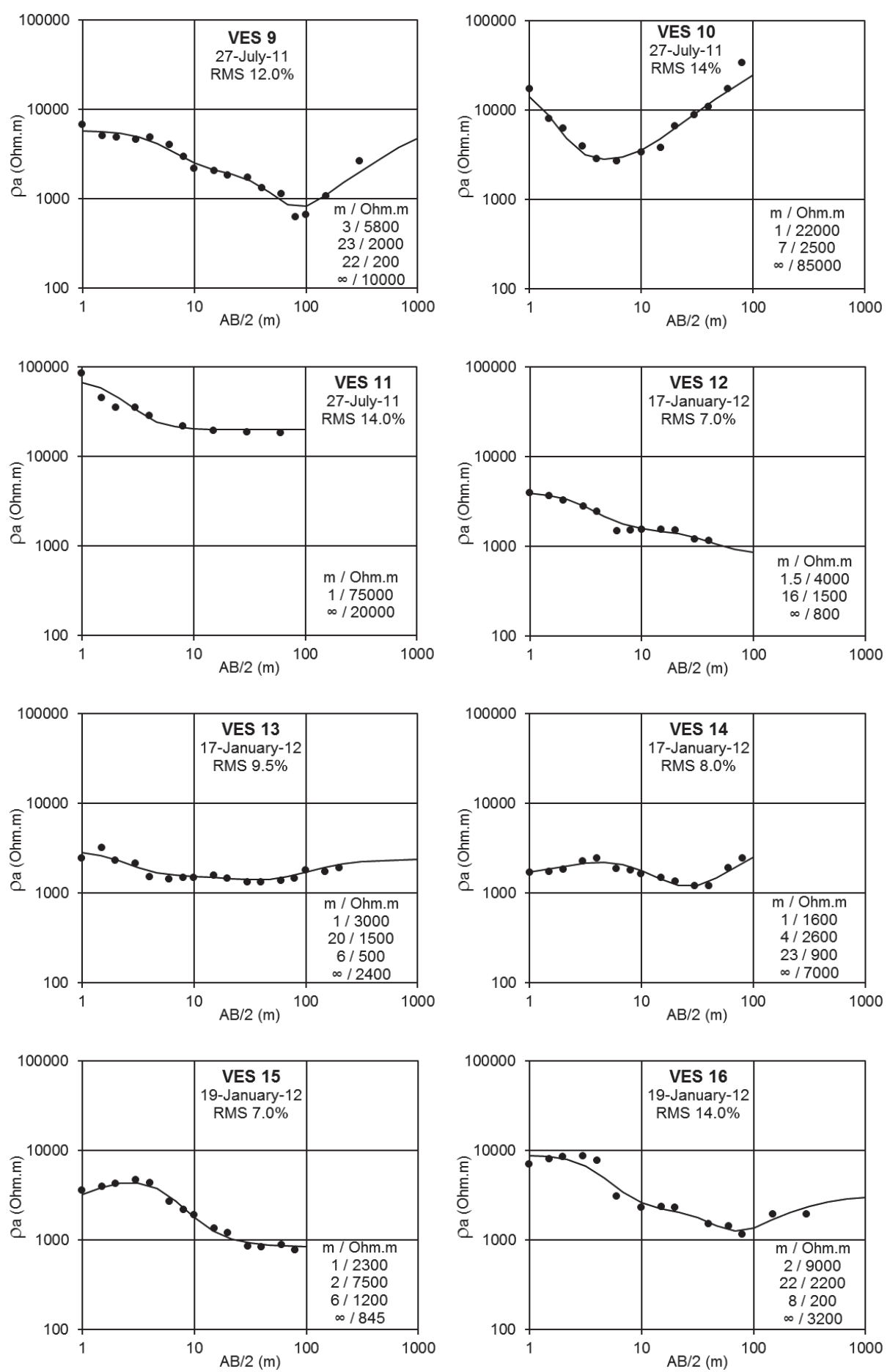

Figure 6 - Curves of vertical electrical soundings (VES) from 9 to 16. The corresponding geoelectrical models are indicated in each graph.

obtained clustering pattern. In our results, all groups showed cophenetic correlation equal or higher than 0.8 (Table 1), indicating a high correlation between the original data matrices and their group representations (Borcard et al., 2011).
The generated groups were analyzed based on the definition of parallel cut lines to the $X$ axis in defining the level of clustering in dendrograms. For purposes of discussing the data, groups containing the last layer of at least one VES were discarded due to the 
varying thickness, which in this case was indefinite. In addition, the groups were considered, as in most cases, to be significantly representative, based on not only statistical aspects but also on relevant theoretical knowledge.

Table 1 - Cophenetic correlation coefficients from the elaborated groups.

\begin{tabular}{|c|l|}
\hline VES 12-9 & 0.85 \\
VES 14-9 & 0.90 \\
VES 15-6 & 0.90 \\
VES 16-5 & 0.90 \\
VES 6-10 & 0.95 \\
VES 13-10 & 0.90 \\
VES 14-11 & 0.90 \\
VES 15-2-4 & 0.85 \\
VES 16-1-7 & 0.85 \\
VES 13-4-3-7-8 & 0.80 \\
\hline
\end{tabular}

\section{DISCUSSION}

After the geophysical data processing for each VES, geoelectrical sections were formulated considering the resulting groups from the cluster analysis, resulting in five groups of geoelectrical sections, as shown in Figures 7, 8, 9, 10 and 11, with their respective dendrograms. In each dendrogram, cut lines and letters for each group obtained were distinguished.

The models containing VES 12-9 and VES 6-10 revealed the geoelectrical behavior in the northeast-southeast direction of Bonita Lake, with the occurrence of VES with three or four layers (Fig. 7). In the geoelectrical section composed by VES12-9, we observed linkage between the dendrogram resulting from cluster analysis and the representation of geoelectrical outlines, except in group A. Thus, there is a surface layer less than four meters thick with resistivity between 5,800 and 4,000 0hm.m, representing dry soil. The posterior layer, with resistivity ranging between 2,000 and 1,500 0hm.m, had a thickness between 23 and 16 meters, indicating the moist soil of the region. VES 12 showed the 800 Ohm.m resistivity value in its last layer. However, in VES 9, the third layer was observed to show a resistivity of $200 \mathrm{Ohm} . \mathrm{m}$ with 22 meters of thickness, correlating to the last layer of VES 12 and representing the saturated region of the subsurface. The fourth layer in the VES 9 model, with a resistivity of 10,000 0hm.m, may indicate subsurface impermeable rock.

The geoelectrical section 6-10, in turn coincides with the clusters, especially in group D, related to the further resistive surface layer and most likely related to the dry soil less than five meters in thickness with resistivity ranging from 22,000 to 28,000 0hm.m. This layer lay over a less resistive layer with a thickness between 7 and 14 meters and resistivity between 1,800 and 2,500 Ohm.m, representing the wetland soil. VES 6 indicated the existence of a saturated area with approximately $400 \mathrm{Ohm} . \mathrm{m}$ resistivity, superimposed on impermeable rock with resistivity equal to $1,600 \mathrm{Ohm} . \mathrm{m}$. The last layer present in VES 10, with a resistivity of 85,000 0hm.m, may represent the presence of Canastra Group quartzite levels.

Corresponding to the north-south direction of the lagoon, the sections containing the VES 14-9 and 13-10 showed between three and four geoelectrical layers (Fig. 8). With respect to the 14-9 geoelectrical model, four layers can be observed in VES 9. The most superficial represents dry soil with higher resistivity and an average thickness of two meters (Fig. 8). Below it was observed the wet zone, present in both VES, with resistivity between 2,600 and 2,000 0hm.m and thickness up to 20 meters, which overlapped a less resistive layer, possibly related to the saturated zone, with an average resistivity of $500 \mathrm{Ohm} . \mathrm{m}$ and a thickness of 22 meters. Subsequently, a layer with an average resistivity of $10,000 \mathrm{Ohm} . \mathrm{m}$ could be observed, indicating the presence of a low permeability rock that may maintain the phreatic aquifer.

VES 13 and VES 10 had four and three layers, respectively. Their analysis allowed us to observe a thin surface layer evident in the dendrogram, with values ranging from 22,000 0hm.m for VES 10 to 3,000 Ohm.m for VES 13, representing dry soil. This layer overlapped a layer with resistivity between 2,500 and 1,500 Ohm.m, up to 15 meters thick, which is characteristic of moist soil. Moreover, a layer of low resistivity (500 0hm.m) in VES 13 can be observed, corresponding to the subsurface saturated zone, superimposed on a layer of 2,400 0hm.m resistivity, also in VES 13, which may indicate impermeable rock. VES 10 also exhibited a third layer with high resistivity, approximately 85,000 0hm.m, correlated with Canastra Group quartzite present in the region.

Observing Figure 9, composed by the 14-11 and 13-4-37-8 sections, we can connect the subsurface behavior in the northwest-southeast direction to the variation of apparent resistivity between three and four layers, as in the previous sections. In the 14-11 section, four and two layers were identified, respectively. In VES 14, although the geoelectrical model consists of four layers, for the purpose of building the geoelectrical section, the two most superficial layers with resistivities of 1,600 and 2,600 Ohm.m, respectively, were combined, confirming the statistical analysis. The total thickness of the superficial package is five meters and may be linked to the dry soil of the unsaturated zone. There is also a layer with low resistivity (900 0hm.m), which may be associated with the subsurface saturated zone. 

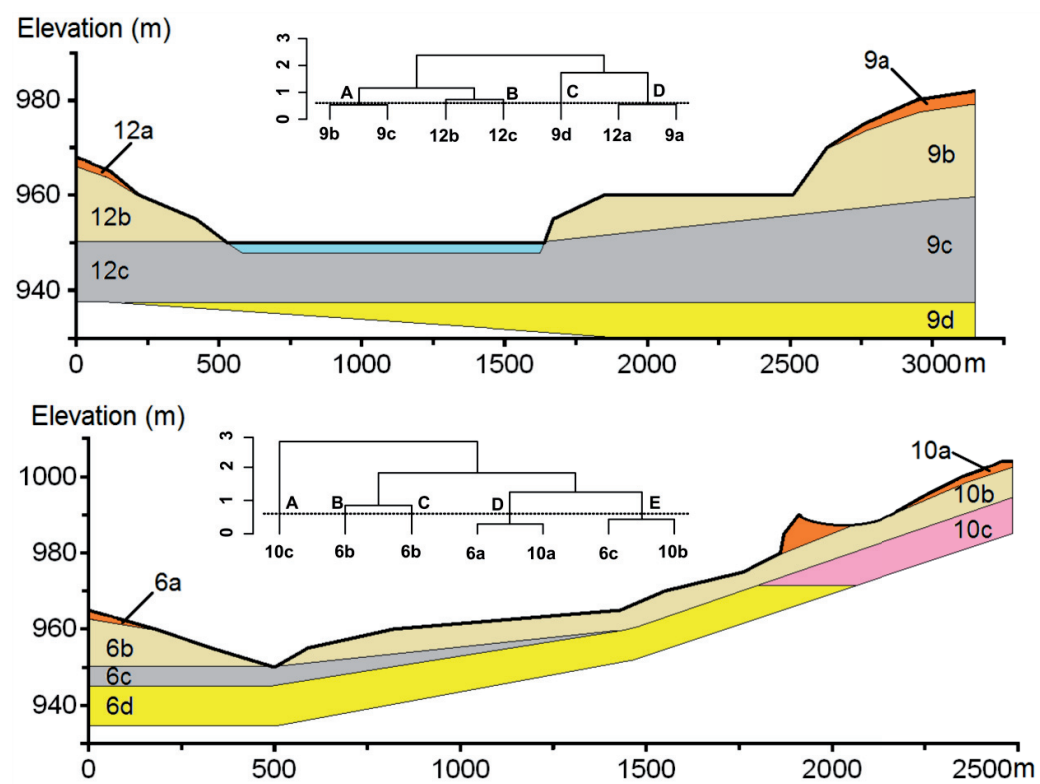

Figure 7 - Geoelectrical sections composed by VES 12-9 (above) and VES 6-10 (below).
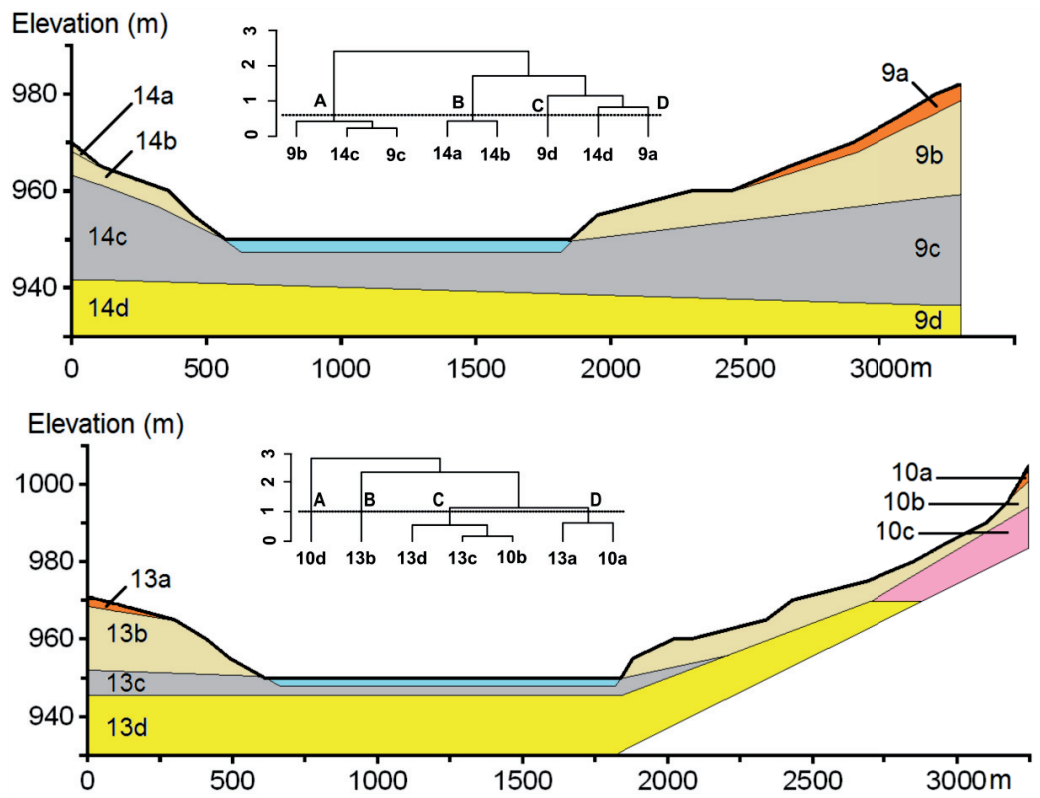

Figure 8 - Geoelectrical sections composed by VES 14-9 (above) and VES 13-10 (below).

The geoelectrical last layer observed in VES 14, with high resistivity, approximately 7,000 0hm.m, may be associated with impermeable rocks. VES 11, with a different configuration from the other VES beyond presenting only two layers, has high resistivity values that may be associated with quartzite levels in the area surrounding the lagoon.

In the 13-4-3-7-8 model, the configuration with four layers is predominant, except for VES 8, with a three-layer model (Fig. 9).
There was an overall recurring pattern in the other geoelectrical sections. A dry soil surface layer prevailed, with higher resistivity, ranging between 16,000 and 3,000 0hm.m, and with an average thickness of two meters (except for VES 7). The next layer of the geoelectrical section, featuring moist soil, showed lower resistivity, between 2,500 and 1,500 0hm.m, and had a thickness of up to 15 meters. The saturated soil showed low resistivity, ranging between 960 and 300 0hm.m. This layer was also observed 

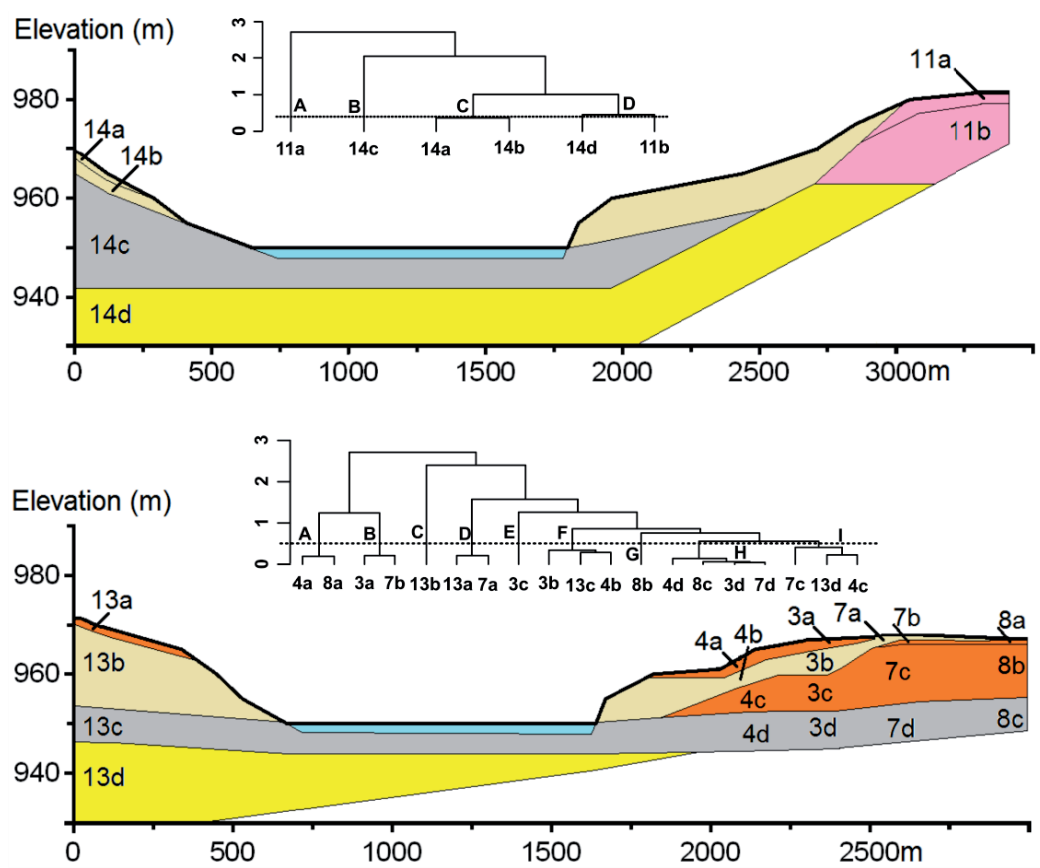

Figure 9 - Geoelectrical sections composed by VES 14-11 (above) and VES 13-4-3-7-8 (below).
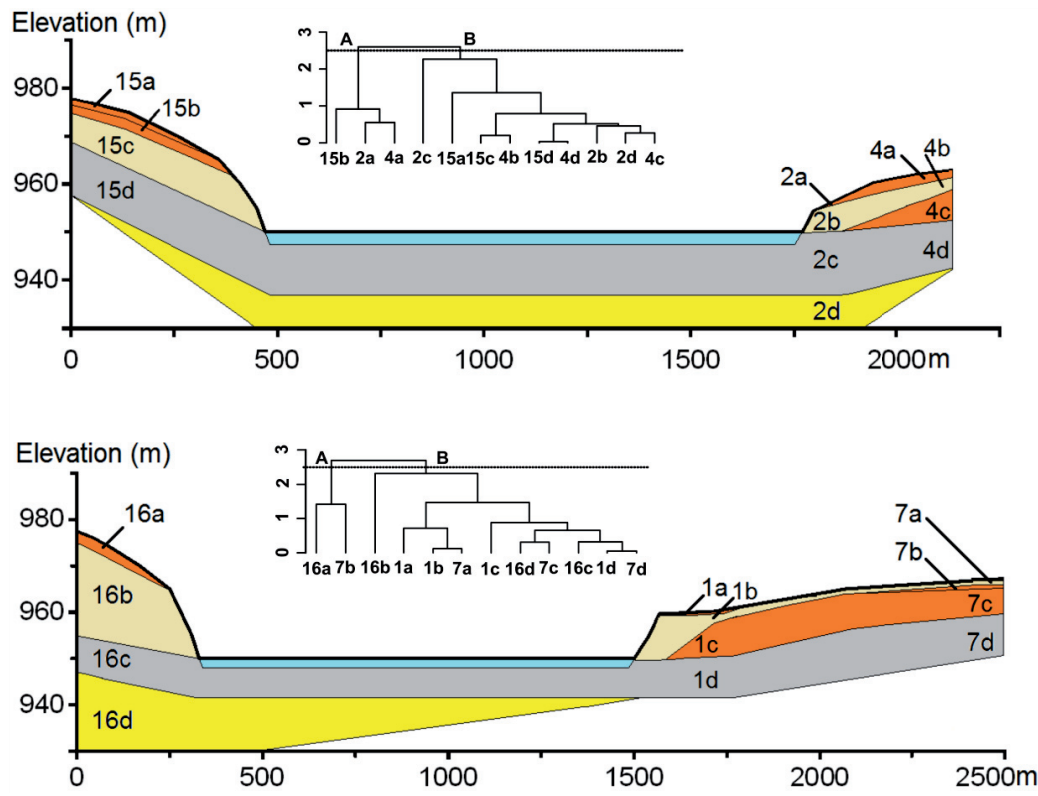

Figure 10 - Geoelectrical sections made up of VES 15-2-4 (above) and VES 16-1-7 (below).

through cluster analysis. The last layer, with infinite thickness, also showed high resistivity values, which may represent impermeable rock. In the 13-4-3-7-8 section, a layer was also observed with resistivity values between 3,000 and 15,000 0hm.m in VES 3, 4,7 and 8, which may characterize a level of more resistive soil.
Sections 15-2-4 and 16-1-7 were representative of the geoelectrical outlines between the northwest and southeast margins of Bonita Lake (Fig. 10). The VES 15-2-4 outline grouped three VES with four layers. Analyzing them together, four geoelectrical layers along the outline can be observed. The first exhibited 
resistivity values between 12,000 and 2,300 0hm.m and thickness between one and three meters, representing the zone with dry soil. The next layer, with a thickness between 5 and 8 meters and resistivity between 2,000 and 1,200 0hm.m, was correlated to moist soil. The third layer, possibly corresponding to the saturated soil zone, had resistivity values between 960 and 300 0hm.m. The last layer in VES 2, with resistivity of 2,500 0hm.m, may represent the impermeable rock that supports the aquifer. In VES 4, a layer was also observed with resistivity values of 3,500 0hm.m, which may characterize a level of more resistive soil.

The combined observation of VES 16, 1 and 7 allowed us to build a geoelectrical section with a predominance of four layers (Fig. 10). In this section, we observed a geoelectrical layer constituted by layers 16a, 7b, 7b, 1a and 1c, which may represent dry soil, as in the statistical grouping. In this layer, the resistivity values ranged from 3,000 0hm.m to 15,000 0hm.m. The wet soil in the unsaturated zone was characterized by an average thickness of 8 meters and resistivity values of 2,200 0hm.m for VES 16, 2,000 0hm.m for VES 7 and 1,500 0hm.m for VES 1. The saturated zone in this region had an average resistivity of approximately 600 Ohm.m. The last geoelectrical layer of VES 16 had a relatively high value that may indicate low permeability rock.

VES 15-6 and 16-5, plotted in the west-east direction of the lagoon, showed a geoelectrical configuration between three and four layers (Fig. 11). The VES 15 model has superficial layers with total thick three meters with resistivity between to 2,300 and 7,500 Ohm.m that is correlated with the first VES 6 layer, with a
26,000 0hm.m resistivity and an approximate thickness of two meters, corresponding to the dry soil, unlike what was observed in the cluster analysis. Through the geoelectrical section, it was possible to observe a second, less resistive layer, which is indicative of the wet soil of the unsaturated zone, with a resistivity of 1,800 0hm.m for VES 6 and 1,200 Ohm.m for VES 15 and a thickness ranging from 14 to 6 meters, respectively. The saturated zone of the subsurface, in turn, exhibited resistivity between 845 and 400 0hm.m and overlaps a fourth layer with approximately 1,600 0hm.m resistivity, present in VES 6. This layer may represent the impermeable rock that sustains the aquifer.

Based on section 16-5, it was possible to visualize a more resistive surface layer with values between 11,700 0hm.m (VES 5) and 10,450 Ohm.m (VES 16) and thickness less than five meters, consistent with the grouping resulting from the cluster analysis. VES 16 exhibited a layer with approximately 2,200 0hm.m resistivity, 22 meters thick, which is representative of the wet soil of the unsaturated zone. In VES 5, in turn, the second layer has a resistivity of 1,000 0hm.m and a thickness of 5 meters and is correlated with the third layer of VES 16, with a resistivity of $2000 \mathrm{hm} . \mathrm{m}$ and a thickness of 10 meters, both indicating the saturated zone (group D of the cluster analysis). A layer with high resistivity, ranging from 3,200 in VES 16 to 1,500 0hm.m in VES 5, bounded the aquifer, as observed in the cluster analysis.

Jha et al. (2008), in preparing geoelectric sections with vertical electrical soundings performed with Schlumberger arrangement in 38 points in a region of India, obtained similar results to

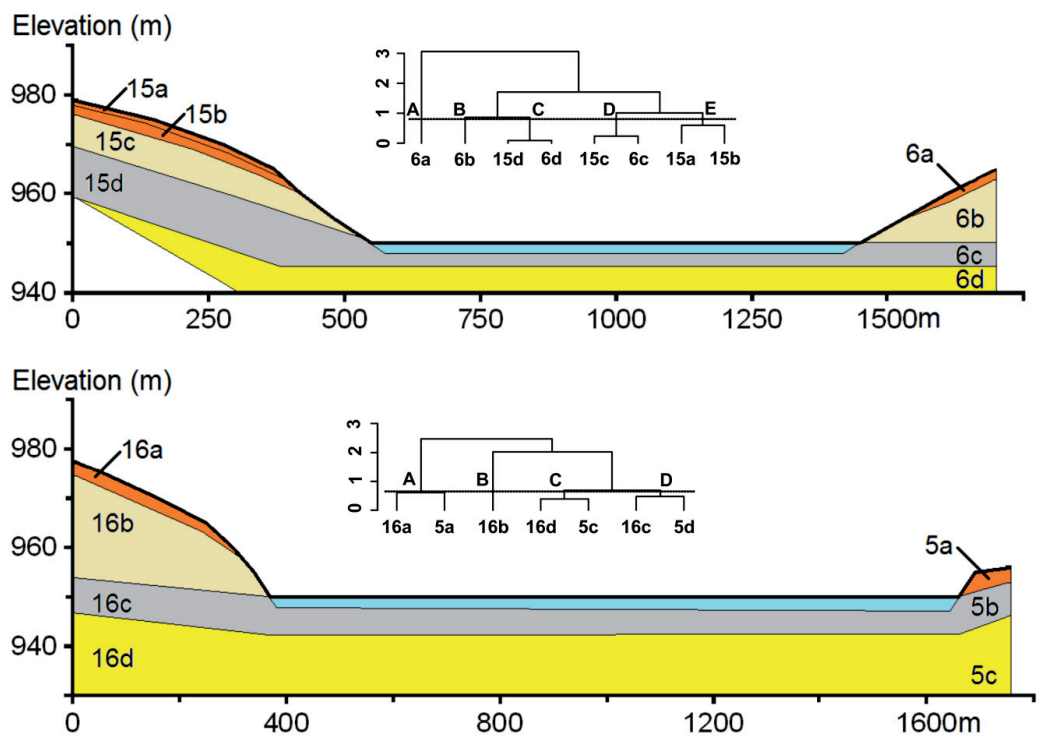

Figure 11 - Geoelectrical sections made up of VES 15-6 (above) and VES 16-5 (below). 
those presented in this study, identifying shallow aquifers ranging from 4 to 19 meters, followed by an impermeable layer of support to the aquifer. Geophysical surveys conducted by Maiti et al. (2012), also in India, they indicated that the geophysical method in question is consistent with concerns the indication of areas conducive to the formation of underground reservoirs, in addition to favoring the interpretation of geological signatures such as fractures, and indication of standards drainage.

Studies on the geology Central Brazil, specifically in the DF region, identified four compressive and one extensive deformation phases. In the compressive east-west oriented phases, folds with a north-south axis were formed, as well as fractures associated with this compression. This compression is associated with the tectonic transport of the Paranoá Group in the east direction, on the Bambuí Group. Afterward, north-south oriented compression formed the structural domes of Brasília, Sobradinho and Pipiripau. This compression may explain the tectonic transport of the Canastra Group northward, on the Paranoá and Bambuí Groups. In this process, in the DF, the Canastra Group molded on the early formation of the São Bartolomeu synclinal fold (Paranoá Group), between the Brasilia and Pipiripau structural domes, with a northwest inclination, arriving in the Maranhão River basin, northwest of the Bonita Lake region. The parallel orientation of drainages in the Bonita Lake region allow the association of its origin with the compressive tectonics that affected the Paranoá, Bambuí and Canastra Groups. After the above-mentioned events, erosion, transport and sedimentation molded the present relief, originating Bonita Lake on a fracture in the north edge of the São Bartolomeu synclinal, the most important occurrence area of the Canastra Group in the DF.

\section{CONCLUSIONS}

The geoelectrical models indicate the existence of a subsurface structure in the Bonita Lake region that consists of dry soil, partially saturated soil, saturated soil and soil or rock with low permeability that allows the existence of an aquifer beneath to the lagoon. This aquifer has variable thickness, and the models indicate values of up to ten meters below the lagoon and up to twenty meters in the surrounding area. This increased thickness in the surrounding area, associated with the higher water levels, indicates that the aquifer supplies water to the lagoon, which arose when the aquifer intercepted a depression in the local terrain.

The only VES that did not intercept the aquifer were the ones numbered 10 and 11. In these VES, higher resistivity values were observed, which were related to the presence of quartzite related to the outcrops of this type of rock existing near VES 10. As indicated on the geological map, the topographically highest region where the VES 10 and 11 readings were taken corresponds to the range of the Canastra Group, and thus, quartzites occur that should belong to this geological unit.

Our current geological knowledge of the central region of Brazil led to the conclusion that the Canastra Group is positioned on the Paranoá Group, including the Lake Bonita region. Thus, the porous materials that constitute the dried, unsaturated and saturated portions in the lagoon region should be associated mainly with Oxisols derived from Paranoá Group rocks, in particular from Clay Metarrithmite and the Psammo-Pelitic-Carbonate unit. If this association is correct, then the low permeability material that sustains the Lake Bonita aquifer corresponds to a clay level of one of the Paranoá Group units mentioned above.

All VES indicate that the aquifer in Bonita Lake has a relatively large lateral extension to the north, east and west of the lagoon; however, in the southward direction, the aquifer appears to be constrained, possibly limited by the Canastra Group quartzites. This restriction may result in a lack of aquifer recharge from the south side, and it is on this side that the lagoon drains and the spring of the Mestre D'Armas River is located. This information is important because it can be used to delineate the hydrogeological basin and the Bonita Lake protection perimeter.

\section{ACKNOWLEDGEMENTS}

The authors thank Luiz Felipe Vitelli Peixoto, Bruno Leandro de Oliveira Maciel, Tamiris de Assis Marques, and Carlos Eduardo Brito Oliveira from the Universidade de Brasília, Applied Geophysics Laboratory and the Research Support Foundation of the Federal District (FAPDF).

\section{REFERENCES}

ANDERBERG, MR. 1973. Cluster Analysis for Applications. New York: Academic Press. 376 pp.

BECKER RA, CHAMBER JM \& WILKS AR. 1988. The New S Language: A programming environment for data analysis and graphics. USA: Wadsworth \& Brooks/Cole.

BIAS ES. 2008. Uso e ocupação do solo: análise temporal. In: FONSECA F0 (Org.). Águas Emendadas. Brasília, Brazil: Secretaria de Desenvolvimento Urbano e Meio Ambiente. p. 433-440

BOBACHEV AA, MODIN IN \& SHEVNIN VA. 2000. IPI2Win. Moscow: Moscow State University/Geoscan-M.

BORCARD D, GILLET F \& LEGENDRE P. 2011. Numerical Ecology with R. New York: Springer. 306 pp. 
CALAMITA G, BROCCA L, PERRONE A, PISCITELLI S, LAPENNA V, MELONE F \& MORAMARCO T. 2012. Electrical resistivity and TDR methods for soil moisture estimation in central Italy test-sites. Journal of Hydrology, 454-455: 101-112.

CLEARY RW. Águas Subterrâneas. 1989. In: RAMOS F, OCCHIPINTI AG, VILLA-NOVA NA, REICHARDT K, MAGALHÃES PC \& CLEARY RW. Engenharia Hidrológica. Rio de Janeiro, Brazil: ABRH/UFRJ. 404 pp.

CUTRIM A0, RUIZ AS, LIPORONI LM, MEDEIROS FA, BARROSO UC \& NASCIMENTO AL. 2007. Sondagem elétrica vertical aplicada em pesquisa hidrogeológica na Bacia do Parecis, MT. Brazilian Journal of Geophysics, 25(2): 131-140.

CUTRIM AO \& SHIRAIWA S. 2011. Prospecção de água subterrânea no sudoeste do município de Rondonópolis(MT) usando sondagemelétrica vertical. Brazilian Journal of Geophysics, 29(4): 745-751.

EDLEFSEN NE \& ANDERSON ABC. 1941. The four electrode resistance method for measuring soil moisture content under field conditions. Soil Science, 51: 367-376.

EMBRAPA. 1978. Levantamento de reconhecimento dos solos do Distrito Federal. Rio de Janeiro, Brazil: EMBRAPA-SNLCS. 455 pp.

EVERITT B. 1974. Cluster Analysis. London: Heinemann Educ. Books. $372 \mathrm{pp}$.

FETTER CW. 1980. Applied Hidrogeology. USA: Prentice Hall. 691 pp.

FREEZE RA \& CHERRY JA. 1979. Groundwater. USA: Prentice Hall. $904 \mathrm{pp}$.

FROHLICH RK \& PARKE CD. 1989. The electrical resistivity of the vadose zone - field survey. Ground Water, 27: 524-530.

FUKUE M, MINATO T, HORIBE H \& TAYAN. 1999. The microstructures of clay given by resistivity measurements. Engineering Geology, 54: 43-53.

GARDNER WH. 1986. Water content. In: KLUTE A (Ed.). Methods of Soil Analysis. Part 1: Physical and Mineralogical Methods. 2nd ed., Madison, American Society of Agronomy/Soil Science Society of America, 493-544.

GORDON AD. 1999. Classification. 2nd ed., London: Chapman and Hall/CRC. 272 pp.

GREENTEC ENVIRONMENTAL TECHNOLOGY. 2010. Zoneamento Econômico Ecológico do Distrito Federal. Available on: <http://www.zeedf.com.br/>. Access on: November 20, 2013.

HARTIGAN JA. 1975. Clustering Algorithms. New York: Wiley. 351 pp.

IBGE. 2007. Manual técnico de pedologia. Rio de Janeiro: Instituto Brasileiro de Geografia e Estatística. 316 pp. Available on: $<$ http://biblioteca.ibge.gov.br/visualizacao/livros/liv37318.pdf>. Access on: May 20, 2013.
IBGE. 2008. Pesquisa Nacional de Saneamento Básico. Rio de Janeiro: Instituto Brasileiro de Geografia e Estatística. 219 pp. Available on: $<$ http://www.ibge.gov.br/home/estatistica/populacao/condicaodevida/ pnsb2008/PNSB_2008.pdf>. Access on: September 13, 2013.

JHA MK, KUMAR A \& CHOWDHURY A. 2008. Vertical electrical sounding survey and resistivity inversion using genetic algorithm optimization technique. Journal of Hydrology, 359: 71-87.

KIRKHAN D \& TAYLOR GS. 1950. Some tests of a four-electrode probe for soil moisture measurement. Soil Science Society of America Proceedings, 14: 42-46.

KOEFOED 0. 1979. Resistivity Sounding Measurements. Amsterdan, Elsevier, $276 \mathrm{pp}$

LEGENDRE P \& LEGENDRE L. 2012. Numerical Ecology. Amsterdam: Elsevier. $990 \mathrm{pp}$.

LOUSADA EO \& CAMPOS JEG. 2005. Proposta de modelos hidrogeológicos conceituais aplicados aos aquíferos da região do Distrito Federal. Revista Brasileira de Geociências, 35(3): 407-414.

MAIA JMF \& BAPTISTA GMM. 2008. Clima. In: FONSECA FO (Org.). Águas Emendadas. Brasília, Brazil: Secretaria de Desenvolvimento Urbano e Meio Ambiente. p. 101-110.

MAITI S, ERRAM VC, GUPTA G \& TIWARI RK. 2012. ANN based inversion of $D C$ resistivity data for groundwater exploration in hard rock terrain of western Maharashtra (India). Journal of Hydrology, 464-465: 294-308.

MARTINS ES, REATTO A, FARIAS MFR, SILVA AV, BLOISE GLF \& CARDOSO EA. 2002. Geologia da margem direita do Córrego Divisa, Bacia do São Bartolomeu -DF, escala 1:10.000. Planaltina, Brazil: Embrapa Cerrados. $21 \mathrm{pp}$.

McQUITTY LL. 1966. Similarity Analysis by Reciprocal Pairs for Discrete and Continuous Data. Educational and Psychological Measurement, 26: 825-831.

MELLO RM \& CASTRO CMSN. 2011. Explotação de água subterrânea no Distrito Federal. Gestão por sistema hidrogeológico. In: Simpósio Brasileiro de Recursos Hídricos, 19. Anais... Maceió, Brazil: Associação Brasileira de Recursos Hídricos.

MIERZWA JC \& HESPANHOL I. 2005. Água na indústria: uso racional e reuso. São Paulo, Brazil: Oficina de textos. 143 pp.

MORAES LL \& CAMPOS JEG. 2008. Hidrogeologia. In: FONSECA FO (Org.). Águas Emendadas. Brasília, Brazil: Secretaria de Desenvolvimento Urbano e Meio Ambiente. p. 122-131.

MURTAGH F. 1985. Multidimensional Clustering Algorithms. In: COMPSTAT Lectures 4. Wuerzburg: Physica-Verlag (for algorithmic details of algorithms used).

NASCIMENTO CTC, PIRES ACB \& MORAES RAV. 2004. Reconhecimento de solos por meio de resistividade elétrica e radiação gama. Revista Brasileira de Geociências, 34(3): 383-392. 
NIAZ A, KHAN R, HAMEED F, ASGHAR A \& MUSTAFA S. 2013. Determination of Ground Water Potential in Mirpur AJ\&K Pakistan, using Geoelectric Methods (vertical electrical sounding). International Journal of Scientific \& Engineering Research, 4: 1896-1903.

NYQUIST JE, FREYER PA \& TORAN L. 2008. Stream bottom resistivity tomography to map ground-water discharge. Ground Water, 46(4): 561569.

ORELLANA E. 1972. Prospeccion Geoelectrica en Corriente Continua. Madrid, Paraninfo, 523 pp.

RHOADES JD. 1979. Inexpensive four-electrode probe for monitoring soil salinity. Soil Science Society of America Journal, 43: 817-818.

RHOADES JD \& INGVALSON RD. 1971. Determining salinity in field soils with soil resistance measurements. Soil Science Society of America Proceedings, 35: 54-60.

RHOADES JD \& VAN SCHILFGAARDE J. 1976. An electrical conductivity probe for determining soil salinity. Soil Science Society of America Journal, 40: 647-651.

SANDBERG SK, SLATER LD \& VERSTEEG R. 2002. An integrated geophysical investigation of the hydrogeology of an anisotropic unconfined aquifer. Journal of Hydrology, 267: 227-243.

SANTOS HG, JACOMINE PKT, ANJOS LHC, OLIVEIRA VA, LUMBRERAS JF, RIZZATO MC, ALMEIDA JA, CUNHA TJF \& OLIVEIRA JB. 2013. Sis- tema Brasileiro de Classificação de Solos. Brasília, Brazil: Embrapa. $353 \mathrm{pp}$.

SEDHAB. 1997. SICAD Sistema Cartográfico do Distrito Federal Escala 1:10.000 Folhas 38, 39, 55, 56. Brasília: Secretaria de Habitação, Regularização e Desenvolvimento Urbano. Available on: < http://www. brasilia.df.gov.br/>. Access on: November 20, 2013.

SNEATH PHA \& SOKAL RR. 1973. Numerical Taxonomy. San Francisco: Freeman. 359 pp.

STEINICH B \& MARÍN LE. 1996. Hydrogeological investigations in northwestern Yucatan, Mexico, using resistivity surveys. Ground Water, 34(4): 640-646.

TELFORD WM, GELDART LP \& SHERIFF RE. 1990. Applied Geophysics. Cambridge: Cambridge University Press. 770 pp.

TIKHONOV AN \& ARSENIN VY. 1977. Solutions of ill-posed problems. New York: Winston \& Sons. 349 pp.

TIRZO AT, VOUDOURIS K \& BASAMI Y. 2012. Estimation of porosity and specific yield by application of geoelectrical method - A case study in western Iran. Journal of Hydrology, 454-455: 160-172.

ZHOU QYJ \& SATO A. 2001. Three-dimensional spatial and temporal monitoring of soil water content using electrical resistivity tomography. Water Resources Research, 37(2): 273-285. 